\title{
FINANCIAL DISTRESS ANALYSIS OF DELISTED COMPANIES ON INDONESIAN STOCK EXCHANGE FOR PERIOD OF 2013-2019
}

\author{
Rabbani Azka*, Achsani Noer Azam, Andati Trias \\ School of Business, IPB University, Indonesia \\ *E-mail: rabbaniazka@gmail.com
}

\begin{abstract}
Companies can perform an Initial Public Offering (IPO) on the IDX to offer their shares to investors. Fluctuations in the $\mathrm{JCl}$ over a period of time, which can have different effects on the stock prices company. If the company fails to strategize and make the right decisions, financial problems can occur for years to come. This can affect the performance of the company on the IDX, which can lead to delisting. There are several delisted companies in 2013-2019. There was a downward trend from 2013 to 2016 but increased from 2017 to 2019. This study took samples of delisted companies on the IDX explored the financial health marked by financial distress. The findings serve to reduce the amount of risk of loss to investors by evaluating the Debt-Service Coverage Ratio (DSCR) as a reference to distinguish companies with good and bad financial health. Next, the sufficiency ratios were tested to see their effect on the DSCR. The results uncovered that long-term debt payments and depreciation-amortization impact have a significant effect on the DSCR. The mapping analysis of the cycle of financial distress showed that the majority of forced delisted companies are in the deterioration of performance and cash flow problem. While the majority of voluntarily delisted companies are in the category of good company. Supporting data from the revenue of forced delisted and voluntarily delisted companies showed a positive trend with the DSCR. Meanwhile, in terms of stock prices, there is no similarity between the chart trends and the DSCR.
\end{abstract}

\section{KEY WORDS}

Financial distress, delisted companies, debt service coverage ratio, revenue, sufficiency ratios, stock prices.

The company offers shares to investors by performing an Initial Public Offering (IPO) on the Indonesia Stock Exchange (IDX). The main requirement for a company to perform an Initial Public Offering (IPO) is to provide the audited financial report of the last two years and is not declared in bankruptcy status by creditors. If that happens, the IDX and the government will impose a temporary stock trading suspension (Safitri \& Fitantina 2016). If improvements are not made for a certain period of time, the IDX and the Capital Market and Financial Institutions Supervisory Agency will forcibly remove the listed company from the stock exchange, which is called forced delisting. In addition, voluntary delisting occurs when companies submit themselves to be removed from the stock exchange by stating reasons. The number of companies delisted from 2013 to 2019 was fluctuated. There was a downward trend from 2013 to 2016 but increased from 2017 to 2019. There were 28 delisted companies, with either forced delisting or voluntary delisting from 2013 to 2019 (IDX, 2020).

Delisting is detrimental to investors since there is no guarantee that their investment can be returned according to the minimum price at the time of purchase. Regulations made by the IDX, Financial Institutions Supervisory Agency, and Financial Services Authority (OJK) have warned and supervised companies to take responsibility. However, the companies had not complied with Financial Institutions Supervisory Agency Law no. 40 of 2007 regarding the fair value of stock prices for public shareholders after delisting. Previous studies regarding SAIP issuers (Sujatmiko \& Suryanti, 2017) and BRAU (Sitorus, 2019) state that delisted companies had not fulfilled their responsibilities to public shareholders. This is due to a lack of support and clarity from the company's management and shareholders to solve the problem. The impact is that negotiations on a fair price for public shares have not been 
proceeded for a long time.

According to Mukhti (2008), the regulations of Financial Institutions Supervisory Agency are limited to monitoring and warning companies before they are effectively delisted. Delisted companies did not do had been instructed after leaving the stock exchange list. Reflecting on the cases that occurred in Indonesia, knowledge regarding the financial health and characteristics of a company that will be delisted as marked by financial distress on the IDX is of the utmost importance. This serves to reduce the amount of risk of loss to investors by evaluating the value of the Debt-Service Coverage Ratio (DSCR) as a reference to distinguish companies with good and bad financial health.

To date, the method of measuring financial ratios in identifying financial distress can predict the sustainability of a company (Priadi, 2019). Therefore, it is important to research in order to provide information on the relationship and factors that affect financial distress. This study involved the variable of Sufficiency Ratios to determine its effect on the DSCR. In addition, the analysis of the mapping of financial distress cycles, revenue, and stock prices was compared with the DSCR as supporting data. The results of this study are expected to help investors in making decisions of companies to be investment destinations.

\section{LITERATURE REVIEW}

A company can be delisted in two ways, by voluntary delisting or force delisting. Voluntarily delisted companies have previously gone through stages and negotiations by shareholders. Shareholders agree to delist the company. The agreement is made officially by holding a General Meeting of Shareholders (GMS) that is attended and approved by half (one half) of the total number of shareholders for a delisting decision or can be referred to as the Going Private Transaction (GPT) (IDX, 2004). Meanwhile, forced delisting has a negative effect on the company's survival in terms of financial or legal that the company cannot prove that it will recover immediately (Djama et al., 2012).

One of the studies related to delisted companies was conducted by Ang (2012) with samples of delisted companies on the New York Stock Exchange, American Exchange, and Nasdaq. Companies from different exchanges revealed factors that cause companies to be delisted including insufficient capital, not paying the financial obligation of companies listed on the exchange, not meeting the guidelines for companies listed on the exchange, and low stock prices. These factors make the stock exchange forcibly remove companies with problems. In addition, tests are carried out to ensure that the company is in a decline in financial health by measuring the status of financial distress. This is in line with research conducted by Raza et al. (2019) on companies in Malaysia that the companies selected by the stock exchange for delisting were indicated to be in financial distress. The factors of companies having financial distress are high loss ratio, high debt ratio, and low total assets. Baza (2011) uses Debt Service Coverage Ratios (DSCR) as a model to assess whether a company is in the category of financial distress. Father, Arlinda (2015) explains that the DSCR model is better than Altman's Z-Score model.

Amuzu (2010) conducted research on companies listed on the Ghana Stock Exchange using sufficiency ratios as an evaluation tool in predicting bankruptcy. This ratio can provide a new perspective on the company to be the target of investment. A company with a higher cash flow adequacy ratio means shows its ability to maintain its financial health. A company with good financial health can be seen from the ability to pay its liability. If the company has problems in completing liability, especially short-term liability, it is indicated as having financial distress with sufficiency ratios as variables that effect it.

\section{METHODS OF RESEARCH}

This study used secondary data from financial statements, four years before the delisting of 11 companies. The sample companies were divided into two groups. They were 6 forced delisted companies and 5 voluntary delisted companies on the Indonesia Stock Exchange (IDX) from 2013 to 2019. The selected companies were tested in four stages of 
the financial distress cycle modified from Outecheva (2007). The first stage is included in the category of good company. The second stage of early impairment is a company's condition when revenue is reduced by more than $20 \%$. The third stage of deterioration of performance is when the company decreases in profit by more than $20 \%$. The fourth stage is the operational cash flow problems. The regression analysis used is a modification from Pranowo et al. (2010). The equation to determine the effect of sufficiency ratios on the DSCR is as follows:

$$
D S C R_{i t}=\alpha+\beta_{1} C F A R_{i t}+\beta_{3} L T D P_{i t}++\beta_{3} D P_{i t}+\beta_{4} R E I N V_{i t}+\beta_{5} D A I_{i t}+\varepsilon_{i t}
$$

Table 1 - Dependent and Independent Variables of the Study

\begin{tabular}{ll}
\hline Dependent Variable & Independent Variable \\
\hline Debt-Service Coverage Ratio (DSCR) & Cash Flow Adequacy Ratio (CFAR) \\
& Long-Term Debt Payment (LTDP) \\
& Dividend Payout (DP) \\
& Reinvestment (REINV) \\
& Depreciation-amortization Impact (DAl) \\
\hline
\end{tabular}

Hypothesis testing used simple logistic regression with descriptive statistics. The hypothesis testing consisted of three stages. The first is the Goodness-of-fit test (Hosmer-Lemeshow test). The second is the overall model test (Log Likelihood-ratio test). The third is the coefficient of determination test (Cox and Snell's R Square enhanced by Nagelkarke R Square test) referring to the research conducted by Antikasari et al (2017).

\section{RESULTS AND DISCUSSION}

The grouping of companies is differentiated based on the financial distress cycle. They are divided into four: good company, early impairment, deterioration performance, and cash flow problem. This is done to clarify the reason for the company being delisted. Based on the results of the analysis in Table 2 , most companies are in the category of deterioration of performance and cash flow problems. The number of companies in the category of cash flow problems increased in year y-0 to 4 companies, which previously was 3 companies in year $y$ 3. This means that the financial condition is at its lowest point indicated by declining revenue that net profit cannot cover the operating costs. It made cash flow become negative.

The majority of voluntarily delisted companies are in the category of the good company every year, especially in year's $y-3$ to $y-1$. The financial health voluntary delisted companies are in stark contrast to the forced delisting group that the majority of which are in the category of cashflow problems. This is evidenced by the fact that 2 voluntary delisted companies are in the category of the good company every year. They are CTRS and SQBB. CTRP is in the category of Good Company from year $y-3$ to year $y-1$. This is because the three companies showed an increase in revenue every year that they maintained the company's financial health.

In addition to the financial distress cycle, the status of the financial health of the delisted company is evaluated by the value of the Debt-Service Coverage Ratio (DSCR). The DSCR refers to previous research with a value of $\geq 1.2$ showing good financial health or nonfinancial distress (Ruster, 1996). Based on Table 3, the DSCR of the majority of forced delisted companies is negative. The factor that makes the DSCR negative is the addition of the annual net loss. There are companies with the lowest negative DSCR of -112.86 in year $y-1$, namely JPRS. The DSCR obtained by JPRS from years y-3 to $y-0$ is negative. In year $y-$ 1 , JPRS experienced the lowest DSCR value because the losses were the biggest in that period. Even though the interest expense was the lowest, it was not balanced with the profits and added the tax burden, making the percentage of DSCR the lowest.

Several voluntary delisted groups leading to delisting had stable, non-financial distress throughout the year because the DSCR was more than 1.2. The companies are CTRS, LAMI, and SQBB. As observed from their financial report, the three companies were profitable. The CTRS had an increase in net profit from year to year so that the DSCR was 
still relatively good. The LAMI that had experienced a decrease in net revenue, had a tax burden and experienced the same thing so that the company's DSCR was more than 1.2. SQBB was classified as having good financial health because from year $y-3$ to $y-0$, it did not have principal liability. In addition, the company's financial condition is also supported by the financial distress cycle. The three companies were in the category of good company. Although LAMI was included in the category of deterioration of performance in year's $y-2$ and $y-0$, it did not interfere with the company's financial health.

Table 2 - The Mapping of financial distress on forced and voluntary delisted companies

\begin{tabular}{|c|c|c|c|c|c|c|c|c|}
\hline \multirow[t]{2}{*}{ Stage } & \multicolumn{4}{|c|}{ Forced Delisting } & \multicolumn{4}{|c|}{ Voluntary Delisting } \\
\hline & $y-3$ & $y-2$ & $y-1$ & $y-0$ & $y-3$ & $y-2$ & $y-1$ & $y-0$ \\
\hline \multirow[t]{4}{*}{ Good Company } & & & SAIP & & & & UNTX & \\
\hline & & & & & CTRP & CTRP & CTRP & \\
\hline & & & & JPRS & $\begin{array}{l}\text { CTRS } \\
\text { LAMI }\end{array}$ & CTRS & $\begin{array}{l}\text { CTRS } \\
\text { LAMI }\end{array}$ & CTRS \\
\hline & & & ATPK & & SQBB & SQBB & SQBB & SQBB \\
\hline Total & 0 & 0 & 2 & 1 & 4 & 3 & 5 & 2 \\
\hline \multirow[t]{5}{*}{ Early Impairment } & SAIP & & & SAIP $^{* *}$ & & $\mathrm{UNTX}^{\star * *}$ & & \\
\hline & $\mathrm{ASIA}^{\star \star}$ & $\begin{array}{l}\text { ASIA }^{* * *} \\
\text { JPRS }^{* * *}\end{array}$ & ASIA & & & & & $\mathrm{CTRP}^{* \star *}$ \\
\hline & & $\mathrm{SIAP}^{\star \star}$ & $\mathrm{SIAP}^{* *}$ & & & & & LAMI $^{* *}$ \\
\hline & $\mathrm{ATPK}^{* * *}$ & ATPK $^{* *}$ & & & & & & \\
\hline & $\mathrm{TMPI}^{\star *}$ & & & $\mathrm{TMPI}^{* * *}$ & & & & \\
\hline Total & 4 & 4 & 2 & 2 & 0 & 1 & 0 & 2 \\
\hline \multirow[t]{6}{*}{ Deterioration of Performance } & & SAIP & & SAIP $^{* *}$ & & UNTX $^{\star * \star}$ & & UNTX \\
\hline & ASIA ${ }^{* \star}$ & ASIA*** & & & & & & CTRP $* * *$ \\
\hline & $\mathrm{JPRS}^{* *}$ & JPRS ${ }^{* * *}$ & JPRS & & & & & \\
\hline & $\operatorname{SIAP}^{\star *}$ & & & $\mathrm{SIAP}^{* *}$ & & LAMI & & LAMI $^{* *}$ \\
\hline & $\mathrm{ATPK}^{\star * *}$ & ATPK $^{* *}$ & & & & & & \\
\hline & $\mathrm{TMPI}^{\star *}$ & TMPI & & $\mathrm{TMPI}^{* * *}$ & & & & \\
\hline Total & 5 & 5 & 1 & 3 & 0 & 2 & 0 & 3 \\
\hline \multirow[t]{5}{*}{ Cashflow Problem } & & $\mathrm{ASIA}^{* * *}$ & & ASIA & UNTX & UNTX $^{\star * \star}$ & & \\
\hline & $\mathrm{JPRS}^{\star \star}$ & $J^{J P R S}{ }^{\star \star \star}$ & & & & & & CTRP $^{\star \star *}$ \\
\hline & $\operatorname{SIAP}^{* *}$ & $\mathrm{SIAP}^{\star *}$ & $\operatorname{SIAP}^{* *}$ & $\mathrm{SIAP}^{\star *}$ & & & & \\
\hline & $\mathrm{ATPK}^{\star \star *}$ & & & ATPK & & & & \\
\hline & & & TMPI & $\mathrm{TMPI}^{* * *}$ & & & & \\
\hline Total & 3 & 3 & 2 & 4 & 1 & 1 & 0 & 1 \\
\hline
\end{tabular}

Note: **: experiencing 2 stages of financial distress simultaneously in 1 year; ***: experiencing 3 stages of financial distress simultaneously in 1 year.

Table 3 - Financial distress status based on DSCR year $y-3$ to $y-0$

\begin{tabular}{|c|c|c|c|c|c|}
\hline Type & Issuer & $y-3$ & $y-2$ & $y-1$ & $y-0$ \\
\hline & SAIP & 3.15 & 0.11 & 85.34 & -0.33 \\
\hline & ASIA & -0.11 & -1.05 & -3.75 & -0.06 \\
\hline Forced & JPRS & -3.02 & -3.47 & -112.86 & -38.78 \\
\hline \multirow[t]{3}{*}{ Delisting } & SIAP & -14.61 & -25.03 & -5.12 & -5.25 \\
\hline & ATPK & -0.45 & -7.07 & -0.10 & -70.16 \\
\hline & TMPI & -4.75 & -0.91 & -0.02 & -26.47 \\
\hline \multirow{5}{*}{$\begin{array}{l}\text { Voluntary } \\
\text { Delisting }\end{array}$} & UNTX & -21.55 & -81.70 & 185.35 & 160.22 \\
\hline & CTRP & 0.90 & 0.87 & 0.79 & 0.48 \\
\hline & CTRS & 4.36 & 9.46 & 9.35 & 5.41 \\
\hline & LAMI & 17.91 & 7.24 & 39.72 & 5.32 \\
\hline & SQBB & 6.36 & 4.60 & 5.06 & 3.71 \\
\hline
\end{tabular}

The study used secondary data from delisted companies, both force delisting and voluntary delisting in the Indonesia Stock Exchange (IDX) from 2013 to 2019. Prior to the logistic regression test, the Goodness-of-fit test (Hosmer and Lemeshow test), the overall model tests (Log-Likelihood Value test), and the coefficient of determination (Cox and Snell's $\mathrm{R}$ Square enhanced by Nagelkarke R Square test) were conducted. Based on the Hosmer and Lemeshow test in Table 4, the Sig. shows a value of $0.645>0.05$, which means that the logistic regression model is acceptable and there is no significant difference and can predict the observed values. 
Table 4 - The Goodness-of-fit test using Hosmer and Lemeshow

\begin{tabular}{llll}
\hline Hosmer and Lemeshow Test & & \\
\hline Step & Chi-square & df & Sig. \\
\hline 1 & 6.024 & 8 & .645 \\
\hline
\end{tabular}

Next, the Log Likelihood-ratio test was carried out to determine the effect of the selected independent variables on the model. The value of block number 0 is 57.682 and the value of block number 1 is 16.147 . Based on Table 5 , it is known that a decrease from 57.682 to 16.147 means that the regression model is in a good category. Furthermore, the test of the coefficient of determination serves to find out how much the dependent variable is explained by the independent variables. This can be seen from the Nagelkerke R Square test of the observation model.

Table 5 - The result of Log-Likelihood Ratio

\begin{tabular}{l|l}
\hline Model & \\
\hline Block & -2 Log Likelihood \\
Block number 0 & 57.682 \\
Block number 1 & 16.147 \\
\hline
\end{tabular}

Referring to Table 6, the Nagelkerke R Square value is 0.836 . This means that the dependent variable can be predicted at $83.6 \%$ by five independent variables. The remaining $16.4 \%$ is explained by other variables outside the study. This shows that sufficiency ratios can affect the DSCR.

Table 6 - The results of the coefficient of determination test

\begin{tabular}{llll}
\hline Model Summary & & \\
\hline Step & -2 Log likelihood & Cox \& Snell R Square & Nagelkerke R Square \\
\hline 1 & 16.147 & .611 & .836 \\
\hline
\end{tabular}

Hypothesis testing using logistic regression was conducted to analyze the effect of the five independent variables of the sufficiency ratio group on the dependent variable (DSCR). Based on Table 7, the five variables have an effect on the DSCR, but only two variables are significant. There are four variables that have a positive effect and one variable has a negative effect. Variables that have a significant effect are long-term debt payment (LTDP) and depreciation-amortization impact (DAI). The two variables are said to have a significant effect on the $5 \%$ significance level because the Sig value $<0.05$. The LTDP variable is positive, which means it has a unidirectional relationship. Apart from LTDP, the variables CFAR, REINV, and DP are seen to be positive but not significant. While the DAI is negative with the opposite relationship to the DSCR.

Table 7 - Hypothesis testing using logistic regression

\begin{tabular}{llllll}
\hline Variables in the Equation & & & & \\
\hline & & $\mathrm{B}$ & Wald & df & Sig. \\
\hline Step $1^{a}$ & CFAR & 8.024 & 3.086 & 1 & .079 \\
& LTDP & .021 & 4.233 & 1 & .040 \\
REINV & .855 & 2.825 & 1 & .093 \\
DP & 3.556 & 1.321 & 1 & .250 \\
DAI & -.472 & 4.521 & 1 & .033 \\
& Constant & -3.333 & 6.627 & 1 & .010 \\
\hline
\end{tabular}

a. Variable(s) entered on step 1: CFAR, LTDP, REINV, DP, DAI.

The variable of CFAR tested in this study has a Sig. value of 0.079 , or a Sig. value > 0.05 , meaning that CFAR has no significant effect and has a positive relationship to DSCR. The result is in contrast to the research conducted by Chen et al. (2005). If the CFAR is higher, the DSCR will also be higher so that the company's financial distress status will be lower. The high CFAR is because the total liability costs are equal to or less than the cash 
generated from operations. In addition, the new asset purchase and dividends should be taken into account to maintain the company's financial health. If these expenditures are not balanced by an increase in cash revenue, it will lower the CFAR.

The results of the study on the variable of REINV ratio showed no significant effect and a positive relationship to DSCR. The Sig. value obtained is 0.093 . It is $>0.05$. The relationship between the REINV ratio and DSCR is positive. This infers that the higher the REINV ratio, the higher the DSCR. According to Amuzu (2010), the REINV ratio is a ratio that does not directly affect the company's financial health because it only describes the company's activities in managing and planning its funds for assets that have a large impact.

The DP ratio shows no significant effect and a positive relationship to the DSCR. The finding of this study is contrary to Wanjiru's (2015) research. The Sig. value of the DP ratio obtained is 0.250 , it is greater than 0.05 . Based on the theory, if the DP ratio increases, the DSCR also increases, which means that the company's financial health is in good condition or the level of financial distress is low. This shows that the company is responsible and maintains the confidence of its investors. These activities can reflect its financial condition that the company's operational activities still have good profits as evidenced by the dividends.

Based on the results of this study, the LTDP ratio had a significant positive effect of 0.021 on the DSCR for every 1 unit increase. This result is in line with the research conducted by Pradana and Achmad (2013). The greater the long-term liability, the greater the DSCR. If the operating cash is negative, the company is in the category of cash flow problems in the financial distress cycle. This shows that long-term liability will be considered not the result of operating cash, but funds obtained due to debt or investment. It is feared that debt, unevenly matched with revenue, will worsen the financial condition of the company. In addition, sooner or later will, the unsettled long-term liability will become the burden of short-term liabilities. One of the factors influencing the DSCR is the amount of principal liability associated with the burden of long-term liabilities.

The variable of DAI shows a significant negative effect on DSCR. Thus, it has an opposite relationship. The coefficient of the DAI ratio is -0.472 . This shows that every increase of 1 DAI unit will decrease the DSCR by -0.472 . If the depreciation and amortization rates increase, the effect on the DSCR is that it will reduce the net revenue. Hence, DSCR as well as the company's financial health are predicted to decrease. The decrease in the company's net profit is included in one of the financial distress cycles, namely deterioration of performance. Based on research carried out by Gulec and Bektas (2019), the relatively high DAI ratio illustrates the accumulated depreciation and amortization of the total cash flow. The smaller the DAI ratio is considered to have more efficient operating activities. Therefore, DAI has an opposite relationship to DSCR because the lower the DAI ratio, the higher the DSCR or the better the financial health of a company.

Figure 1 shows the revenue received by the forced delisted companies associated with stock movements per year. Earnings and stock price movements support the company's DSCR to ensure that the company is in good financial condition. Based on the results on the forced delisted companies, the majority of companies have the same trend between DSCR and revenue. If the DSCR is in the category of financial distress, the revenue decreased. Meanwhile, stock prices did not experience the same pattern as the DSCR as shown in Figure 1, which did not change from $y-3$ to $y-0$.

The revenue of the majority of voluntarily delisted companies tends to increase as indicated by an increase in the total revenue each year. The decrease only occurred in CTRP and LAMI in year's $y-1$ to $y-0$. This also caused the two companies to experience a decrease in net profit of more than $20 \%$ so that they were included in the category of deterioration of performance in year $y-0$. Based on the results obtained, all voluntarily delisted companies have a DSCR in the category of non-financial distress. Supposedly, if the DSCR increases, the share price will also increase, but there are three out of five companies that do not experience an increase in stock prices, namely UNTX, LAMI, and SQBB (Figure 2). 

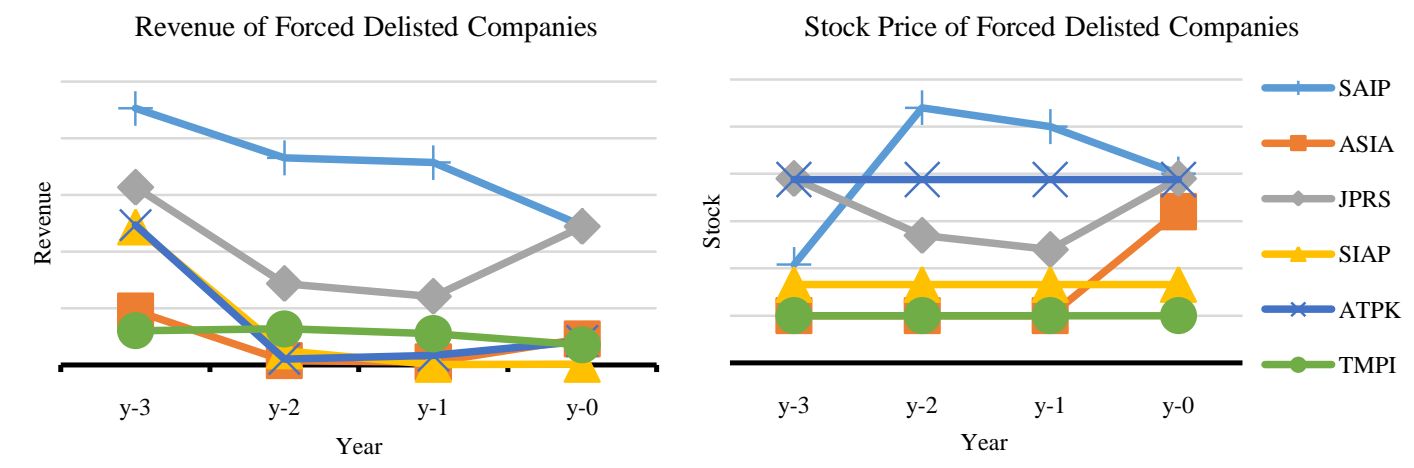

Figure 1 - Revenue and Stock Price of Forced Delisted Companies in year's y-3 to y-0

Revenue of Voluntary Delisted Company

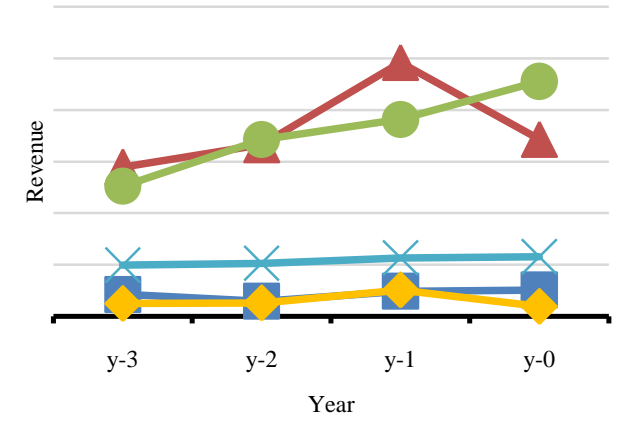

Stock Price of Voluntary Delisted Company

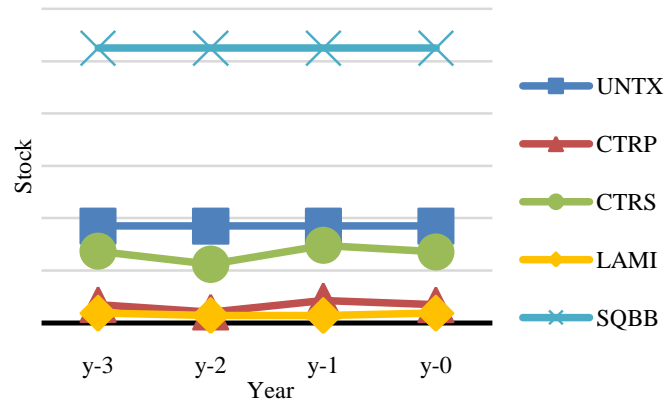

Figure 2 - Revenue and stock price of voluntarily delisted companies in years $y-3$ to $y-0$

The majority of the stock price is not influenced by the company's fundamental factors. It is influenced by external factors beyond the control of the company's management. Indrawan (2018) used Altman's Z-score to determine financial distress. The finding of his study does not show any relationship to the company's stock price movements. Research related to external factors on stock prices has been proven by Azizah (2019) that the influence of the Rupiah exchange rate on the Dollar, the economic growth rate, and inflation affect stock prices by $93.08 \%$.

\section{CONCLUSION}

The research was conducted on forced delisted and voluntarily delisted companies by testing the independent sufficiency ratios on the DSCR. The independent variables that have a significant effect on the five ratios are the long-term debt payments and the depreciationamortization impact ratios. In addition, a mapping analysis on delisted companies between the DSCR and the financial distress cycle was carried out. The results showed that financial distress could be proven in the forced delisted companies. However, it was not proven in voluntarily delisted companies. This is supported by the declining revenue of forced delisted companies. It is different from the stock price data which has not shown a significant difference. Hence, the stock price cannot be used as a reference.

\section{REFERENCES}

1. Ang TCC. 2012. Understanding the Distress Puzzle: Surprises in the Pre-Delisting Period. Financial Markets \& Corporate Governance Conference. [Internet]. [Diunduh pada 3 Juni 2020]. Tersedia dari https://papers.ssrn.com/

2. Amuzu MS. 2010. Cash Flow Ratio As a Measure of Performance of Listed Companies in Emerging Economies: The Ghana Example [disertasi]. Ghana (GH): St. Clements University. 
3. Antikasari TW, Djuminah. 2017. Memprediksi Financial Distress dengan Binanry Logit Regression Perusahaan Telekomunikasi. Jurnal Keuangan dan Perbankan. 21 (2): 265275.

4. Arlinda. 2015. Pengaruh Kebijakan Bisnis Operator Telekomunikasi Indonesia terhadap Kinerja Keuangan dan Resiko Kebangkrutan [tesis]. Bogor (ID): Institut Pertanian Bogor.

5. Azizah N. 2019. Analisis Financial Distress dan Pengaruhnya terhadap Harga Saham Perusahaan Sektor Pertanian Terdaftar di Bursa Efek Indonesia [tesis]. Bogor (ID): Institut Pertanian Bogor.

6. [BEl] Bursa Efek Indonesia. 2004. Keputusan Direksi PT Bursa Efek Jakarta [internet]. [Diunduh pada 11 April 2020]. Tersedia dari https://www.idx.co.id/media/8341/peraturan_i_i_penghapusan_delisting_pencatatan_kem bali_relisting_saham.pdf

7. [BEI] Bursa Efek Indonesia. 2020. Aktivitas Pencatatan [internet]. [Diunduh pada tanggal 11 April 2020]. Tersedia dari https://www.idx.co.id/perusahaan-tercatat/aktivitaspencatatan/.

8. Baza AU. 2011. Financial Distress and Its Determinants in Selected Beverage and Metal Manufacturing Firms in Ethiopia [tesis]. Ethiopia (ET): Addis Ababa Univesity.

9. Chen CL, Chang FH, Yen G. 2005. The Information Contents of Auditor Change in Financial Distress Prediction - Empirical Findings from the TAIEX-listed Firms. The $13^{\text {th }}$ Conference on Pacific Basin Finance, Economics and Accounting on June 10-11. United State of America (US): Rutgers University.

10. Djama C, Martinez I, Serve S. 2012. What Do We Know About Delistings? A Survey of The Literature. Theorie Economique, Modelisation et Applications (THEMA). DOI: 10.2139/ssrn.1968352.

11. Gulec OF, Bektas T. 2019. Cash Flow Ratio Analysis: The Case of Turkey. The Journal of Accounting and Finance August 2019. 247-262.

12. Indrawan B. 2018. Analisis Financial Distress dan Pengaruhnya terhadap Harga Saham Perusahaan Ritel di Indonesia Periode 2014-2017. Jurnal IImiah Universitas Brawijaya, 7 (2): 1-16.

13. Mukhti. 2008. Perlindungan Hukum bagi Investor Publik dalam Penghapusan Pencatatan (Delisting) Saham pada Kegiatan Pasar Modal Indonesia [tesis]. Medan (ID): Universitas Sumatera Utara.

14. Outecheva N. 2007. Corporate Financial Distress: An Empirical Analysis of Distress Risk [disertasi]. Rusia (RU): University of St. Gallen.

15. Pranowo K, Achsani NA, Manurung AH, Nuryartono N. 2010. Determinant of Corporate Financial Distress in an Emerging Market Economy: Empirical Evidence from the Indonesian Stock Exchange 2004-2008. International Research Journal of Finance and Economics. 52 (1): 81-90.

16. Priadi RA. 2019. Dampak Faktor Eksternal dan Internal terhadap Financial Distress Perusahaan Manufaktor Go Public Sub Sektor Makanan dan Minuman Tahun 2008-2017 [tesis]. Bogor (ID): Institut Pertanian Bogor.

17. Raza A, Hussin WNW, Majid JA. 2019. Delisting of firms in Malaysia; what the financial conditions and auditor reports reveal? Advances in Social Sc. Research J. 6(5): 90-97.

18. Ruster J. 1996. Mitigating Commercial Risks in Project Finance. Private Sector Development Department. New York (US): The World Bank.

19. Safitri E, Fitantina. 2016. Analisis Prediksi Kebangkrutan pada Perusahaan yang TerDelisting dari Bursa Efek Indonesia (BEI). Jurnal IImiah STIE MDP. 6 (1): 16-28.

20. Sitorus LR. 2019. Tindakan Yuridis Tindakan Delisting oleh Bursa Efek Indonesia dan Perlindungan Pemegang Saham (Studi Kasus: PT Berau Coal Energy Tbk). Dialogia luridica. 10 (2): 19-33.

21. Sujatmiko B, Suryanti N. 2017. Perlindungan Hukum Bagi Investor pada Perusahaan Terbuka yang Pailit Ditinjau dari Hukum Kepailitan. Jurnal Bina Mulia Hukum. 2(1):15-25.

22. Wanjiru FW. 2015. The Effect of Dividend Pay Out Ratio on The Financial Performance of Companies Listed on The Nairobi Securities Exchange [tesis]. Nairobi (KE): University of Nairobi. 